\title{
Becoming a missional church: The struggle of the Lesotho Evangelical Church in Southern Africa or Paris Evangelical Missionary Society in Meadowlands, Soweto
}

\begin{tabular}{|c|c|}
\hline \multicolumn{2}{|c|}{$\begin{array}{l}\text { Authors: } \\
\text { Leonard Tsdiso Kganyapa }^{1} \\
\text { Thias Selaelo Kgatla }^{1}\end{array}$} \\
\hline \multicolumn{2}{|c|}{$\begin{array}{l}\text { Affiliations: } \\
\text { 'Department of Science of } \\
\text { Religion and Missiology, } \\
\text { Faculty of Theology, University } \\
\text { of Pretoria, South Africa }\end{array}$} \\
\hline \multicolumn{2}{|c|}{$\begin{array}{l}\text { Project leader: T.S. Kgatla } \\
\text { Project number: } 04486863\end{array}$} \\
\hline \multicolumn{2}{|c|}{$\begin{array}{l}\text { Description: } \\
\text { This research is part of the } \\
\text { project, 'The role of German } \\
\text { Churches in the demise of } \\
\text { apartheid in South Africa', } \\
\text { directed by Prof. Dr Thias } \\
\text { Kgatla, Department of } \\
\text { Missiology and Science of } \\
\text { Religion, Faculty of Theology, } \\
\text { University of Pretoria. }\end{array}$} \\
\hline \multicolumn{2}{|c|}{$\begin{array}{l}\text { Corresponding author: } \\
\text { Selaelo Kgatla, } \\
\text { thias.kgatla@up.ac.za }\end{array}$} \\
\hline $\begin{array}{l}\text { Dates: } \\
\text { Received: } 15 \\
\text { Accepted: } 02 \\
\text { Published: } 24\end{array}$ & $\begin{array}{l}\text { uly } 2016 \\
\text { Sept. } 2016 \\
\text { Nov. } 2016\end{array}$ \\
\hline \multicolumn{2}{|c|}{$\begin{array}{l}\text { How to cite this article: } \\
\text { Kganyapa, L.T. \& Kgatla, T. S., } \\
\text { 2016, 'Becoming a missional } \\
\text { church: The struggle of the } \\
\text { Lesotho Evangelical Church in } \\
\text { Southern Africa or Paris } \\
\text { Evangelical Missionary } \\
\text { Society in Meadowlands, } \\
\text { Soweto', HTS Teologiese } \\
\text { Studies/Theological Studies } \\
72(4) \text {, a3777. http://dx.doi. } \\
\text { org/10.4102/hts.v72i4.3777 }\end{array}$} \\
\hline \multicolumn{2}{|c|}{$\begin{array}{l}\text { Copyright: } \\
\text { (c) 2016. The Authors. } \\
\text { Licensee: AOSIS. This work } \\
\text { is licensed under the } \\
\text { Creative Commons } \\
\text { Attribution License. }\end{array}$} \\
\hline Read onli & \\
\hline 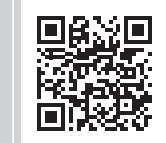 & $\begin{array}{l}\text { Scan this QR } \\
\text { code with your } \\
\text { smart phone or } \\
\text { mobile device } \\
\text { to read online. }\end{array}$ \\
\hline
\end{tabular}

Authors:

Leonard Tsdiso Kganyapa ${ }^{1}$

Thias Selaelo Kgatla

Faculty of Theology, University

Project leader: T.S. Kgatla

Project number: 04486863

Description:

project, 'The role of Germa Churches in the demise of directed by Prof. Dr Thias

Kgatla, Department of

Missiology and Science of

Religion, Faculty of Theology,

Corresponding author:

Selaelo Kgatla,

Dates:

Accepted: 02 Sept. 2016

How to cite this article: Kganyapa, L.T. \& Kgatla, T. S. 2016, 'Becoming a missiona Southern Africa or Paris Evangelical Missionary Society in Meadowlands, Soweto', HTS Teologiese Studies/Theological Studies 72(4), a3777. http://dx.doi. org/10.4102/hts.v72i4.3777

Copyright: Licensee: AOSIS. This work is licensed under the Creative Commons Read online: to read online.
The existence of the Lesotho Evangelical Church in Southern Africa (LECSA) and Paris Evangelical Missionary Society (PEMS) in the western areas of Johannesburg, South Western Township (Soweto) and, more poignantly, Meadowlands and their forced removal experience are succinctly captured. The struggle of the LECSA and PEMS Meadowlands Parish in becoming a missional ecclesia in a sea of missional challenges in her context is vividly spelt out. They, inter alia, include constitutional matters, language policy, finances, ministerial preparation, lay-ministry development, institutionalisation of ministry, unity issues, prophetic ministry, mission and evangelism. The researcher, then, proposes an intervention - of course not a perfect one - that perhaps will galvanise the LECSA and PEMS Meadowlands Parish members to improve on what they have been doing and become a missional ecclesia in her context, Meadowlands.

\section{Introduction}

This article was influenced by the researcher's need to understand the Lesotho Evangelical Church in Southern Africa (LECSA) and Paris Evangelical Missionary Society (PEMS) as a denomination, as he was approached by their Meadowlands Parish to take up ordained ministry there. The researcher was also approached by the Gauteng (South Africa) Presbytery Committee to be part of the Evangelism and Mission Commission (Komisi ea Lentsoe) and assume the position of secretary.

The researcher's seminal ministerial involvement was wrought with several challenges and necessitated an in-depth study of the LECSA and PEMS Meadowlands Parish as a missional church. Among others, the challenges that the LECSA and PEMS Meadowlands were facing were pertaining to language policy, finances, ministerial formation, unity issues, membership exodus, lay-ministry development, institutionalisation of ministry, ecumenical participation, mission and evangelism. Moreover, all these were making it extremely difficult for the LECSA and PEMS Meadowlands Parish to become missional in her local context: Meadowlands, Soweto. The article is an attempt, in a small way, to reflect on the LECSA and PEMS Meadowlands Parish struggle to become a missional ecclesia in her locality.

The research methodology employed is Positive Deconstruction (from Pollard 1997) which refers to the process whereby people are being helped to deconstruct (take apart) what they believe in order to look carefully at the belief and move forward in their work. The process is positive because the deconstruction is done in a positive way - in order to replace it with something better (Pollard 1997:44-45).

Positive Deconstruction, as a methodology, is employed in this article on the one hand to identify what is positive in the missional praxis of the LECSA and PEMS Meadowlands Parish and endeavour to retain or conserve it. And, on the other hand, it is employed to identify what is not effective and purge the church of it. However, in order to truly retain what is working, dismantling must happen and the church must get rid of that which has been constructed in the past and has become obsolete.

Note: This article represents reworked aspects of the MA thesis of Rev L.T. Kganyapa, titled 'The struggle of the Lesotho Evangelical Church in Southern Africa (LECSA)/Paris Evangelical Missionary Society (PEMS) in Meadowlands, Soweto, in becoming a missional ecclesia in a local context', completed under the supervision of Prof. Dr T.S. Kgatla, Department of Science of Religion and Missiology, Faculty of Theology, University of Pretoria, South Africa. 
Overarching questions were then developed to inform the article and, of course, following the qualitative method, undergirded by the postmodernist perspective (Mason 2002:3-4; Guba in Swinton \& Mowat 2006:34-35). The article is aimed to address, inter alia, these questions:

- Whose prerogative is it at LECSA and PEMS regarding missions? With whom does the buck stop, when it comes to missions at LECSA and PEMS?

- What do founding documents of the LECSA and PEMS state with regard to missions?

- How does their theology of missions at LECSA and PEMS work itself out in the structures and life of the church?

- Does LECSA and PEMS need to develop a new theology of missions?

- What is the experience of other churches in the tradition of the LECSA and PEMS and are there lessons to be learnt?

- Is LECSA and PEMS Meadowlands Parish growing?

- How can LECSA and PEMS Meadowlands Parish become a missional ecclesia in her context?

\section{A brief historical survey of the Lesotho Evangelical Church in Southern Africa and Paris Evangelical Missionary Society}

The LECSA and PEMS, as a Protestant denomination, was founded during the mission enterprise historical epoch of the French missionaries per invitation of the founding father and king of the Basotho nation, Morena Moshoeshoe (Du Plessis 1965:passim; Gill et al. 2009:48). The first generation (1833) of French missionaries in Lesotho was Eugene Casalis, Thomas Arbousset and Constant Gosselin, assisted by African people in the likes of Adam Krotz (a Christian Griqua chief) and his team, which included Basotho interpreters, who welcomed and gave residence to Basotho in his land long before the arrival of French missionaries (Casalis 1971:136-140, 182-183; Mohapeloa 1985:1).

This early partnership between the Europeans and Africans is not always acknowledged and celebrated in mission historiography. Long before the French missionaries encountered the Basotho of Lesotho there was already a handful of Basotho who had embraced the Christian faith from the mission stations in other parts of the Cape Colony. Adam Krotz offered to be their guide and aide and brought with him his cortège of hunters, Booi Armans, Hans Lubbe, a Mosotho interpreter, Sépéami, and three other Basotho and an army of Bushmen (Casalis 1971:140, 182-183). These groups of Basotho were very helpful, or should one say useful, to the early first generation of the French missionaries in propagating the Gospel. This fact was also evinced when the second generation of missionaries in the person of Francis Coillard, his family and 24 Basotho Christians travelled to the Barotsi people near the Zambezi River and founded the Western Province Presbytery which today is known as the United Church of Zambia (Couzens 2003:396; Du Plessis 1965:324; Molao oa Motheo 2012:2).
The French mission - a product of Le Réveil (The Awakening) which was a reaction to the materialism and rationalism that had entered the Reformed Churches during the Enlightenment and had an interdenominational flavour - did not have a clearly articulated theological motive for mission or rather a theology of mission. They followed the model of the London Missionary Society (LMS) which was informed by the mercantile company model of doing business (Bianquis 1930:43). However, individual missionary's motive, such as Eugene Casalis, was informed by their personal conviction that the heathens or savages needed to be saved from eternal damnation and hell and be imported into the European civilisation because they considered their culture as more compatible with the Christian faith (Walls in Bosch 1991:330; De Clark 2000:48).

The Constantinian model of Christianising the Basotho did bear fruit, but only in the royal family, and it was not sustainable. For every time when there was a misunderstanding or discord between the royal house and the missionaries, the Basotho would revert to their ancestral ways of doing things, for example lobola-mahali, initiation schools (male circumcision), polygamy, levirate and other cultural practices. Thus, the missionaries decided to directly Christianise ordinary members of the Basotho nation (Sundkler \& Steed 2000:380). Around the 1860s Rev. Tiyo Soga was visiting in Basutoland, and when he saw the Paris Missionary Society stations and Christian natives he was not impressed. He observed that the Basotho were lagging far behind his Xhosa people even in outward things (Williams 1978:37).

In 18-19 April 1964, the Church of the Basotholand came of age (Thuthuho) and was handed over to the Basotho hegemony. The researcher laments the fact that there is no acknowledgement in the historiography of the LECSA and PEMS of the external forces that were at play, both continentally and internationally, and left the French mission with no choice but to relinquish control over to the Basotho church (Mohapeloa 1985:46-47). Sadly, the very Basotho leadership have shunned employing words like independence or autonomy to describe the events of 18-19 April 1964, but rather prefer the phrase coming of age (Thuthuho) (Bosch 1991:2, 22-35). For the researcher this smacks of the continued dependency of the African Church on the Occident Church in a post-colonial Africa - a mother and daughter or master and slave church relationship which the ecumenical body such as World Council of Churches was and is still discouraging (Bosch 1991:459; Saayman 2010:6, 7).

The current ministry and mission of the LECSA/PEMS, whose genesis is mostly attributed to the 'Mission', is sacrosanctly preserved and maintained by the Basotho hegemony. Today, Lesotho is $96 \%$ Christian and LECSA and PEMS boasts 12 Presbyteries (11 in Lesotho and 1 in Gauteng, encompassing South Africa as a whole) and a total of 109 parishes (14 are in South Africa). The LECSA and PEMS does quite a lot in terms of missions through her several institutions and group formations that are based at her headquarters in 
Morija, Lesotho, but very little in South Africa (Gauteng). The LECSA and PEMS was known as Lesotho Evangelical Church (LEC)/PEMS prior to 2012, and the words 'in Southern Africa' were appended to reflect the extension of the church's ministry and mission beyond the border of Lesotho.

\section{Lesotho Evangelical Church in Southern Africa and Paris Evangelical Missionary Society in the western areas of Johannesburg}

The history of South Western Township (Soweto) is intertwined with that of the western areas of Johannesburg. The western areas of Johannesburg covered Sophiatown, Newclare, Martindale and Western Native Township (WNT). Sophiatown and Newclare were under free lease hold and more multiracial communities, while WNT was under municipal control and used mainly for black Africans. Martindale, in contrast, was designated mainly for white people (Kagan 1978)

The western areas of Johannesburg experienced an influx of migrants looking for employment in the areas of Johannesburg and this resulted in overcrowding (Goodhew 2004:1-2). Though endowed with the best cultural talent (Modisane 1990:xviii; Purkey \& Stein 1993:iv; Thema 1999:45, 46) - in writing, performing arts, sports and, of course, political leadership - the areas were inflicted by numerous social ills of their day including gangsterism, illegal beer brewing and excessive drinking of alcohol, hooliganism, prostitution, unemployment, thuggery, delinquency and single parenting.

The Basotho who lived in the areas were reputed as beer brewers, especially Basotho women, and their youngsters were part of the gang subculture (Bonner 1990; Goodhew 2004:4; Thema 1999:17). The Basotho, as migrants, displayed disloyalty to the liberation agenda of people of the areas and they would, from time to time, sabotage the struggle and collaborate with the oppressive system of the day (Goodhew 2004:passim)

Even though there was racial harmony in the communities, a lack of housing turned the area into a slum - especially in Sophiatown and Newclare (Modisane 1990:14, 131, 164). The apartheid government came up with legislation and schemes to forcefully relocate these communities, due to their annoyance with the racial harmony of these communities and the dissatisfaction of their white-only neighbours (Brown 2013:17; Goodhew 2004:121).

The black Africans resisted the move and started a number of campaigns geared towards fighting against the forced removals (Brown 2013:39; Goodhew 2004:xxi; Purkey \& Stein 1993:viii). The church that was overtly alongside the 'masses' was the Anglican Church in the person of the missionary and pastor Rev. Trevor Huddleston (Thema 1999:27). Churches in the areas, across denominational lines, were indeed doing missions through education, orphanages and also ministering to the communities in various ways (Ashley 1980:25; Goodhew 2004:88-89). However, the LECSA and PEMS and her leadership then seemed to have been quiescent because there is no evidence of her activism during this period.

The researcher takes into account, and laments, the fact that the arch engineers and architects of racist apartheidsegregationist policies were church ministers and theologians attached to the Calvinist Dutch Reformed Church, namely Rev. Dr Malan and Dr Verwoerd among others (Modisane 1990:179-180).

In their quest to resist the forced removals, a rift was exposed between ratepayers and tenants (Purkey \& Stein 1993:ix). There was ineffective strategy in their resistance for they were divided in the struggle. Besides the heavy deployment and presence of the police and army, the promise of a better life to where the tenants were to be resettled was palatable to many; thus, the resistance was not sustainable (Modisane 1990:109). An interesting fact is the collaboration of the gangs with the communities in their resistance to the forced removals and the reduction in crime against the communities (Purkey \& Stein 1993:xi). Finally, the western areas of Johannesburg were cleared of the 'black spot' and they were renamed. The PEMS church building still exists and is situated at the corner of Kretzchmar and Du Plessis Street, 497 in today's Westbury, formerly known as WNT.

The perennial problems of Soweto have, since its inception, included poor housing, overcrowding, high unemployment and poor infrastructure (Beavon 2004:127; Kane-Berman 1978:58). In principle, Soweto, the abbreviation for South Western Town, is an extension of the racist segregation policies of the apartheid government of the Union of South Africa under the leadership of the Herenigde Nasionale Party - the Reunited National Party and later the Nationalist Party (Seekings 2011). Soweto is known to have a propensity to resistance and riots because of its history of struggle against unjust racist apartheid laws or policies (Beall, Crankshaw \& Parnell 2003:58). It is on record that numerous struggle heroes and heroines lived in and walked on the dusty streets of Soweto. A number of resistance campaigns were launched and led from the internationally renowned township, Soweto (Alexander et al. 2013:42; Kane-Berman 1978:1).

People's struggle against injustice always presents a missional opportunity for the church and little is recorded regarding the LECSA and PEMS' involvement. The LECSA and PEMS Gauteng (South Africa) does not feature anywhere regarding the church's missional involvement in the people's struggle either institutionally or as individual members of the denomination.

Recent developments in the township evince a massive influx of migrants and statistics show that migrants who found 
themselves in Soweto are mostly young and are struggling with unemployment (Von Holdt \& Webster 2005:6). This phenomenon presents the church with a missional opportunity to tap into, for young people are not only a future resource for the church's missional agenda but a present one. The reality is that Soweto has become a class township where some live in opulence while the majority find themselves in abject poverty (Alexander et al. 2013:48-49). The vision and promises of 1994 and the liberation struggle are still to be realised (Ngwane 2003:44).

\section{Meadowlands Parish of Lesotho Evangelical Church in Southern Africa and Paris Evangelical Missionary Society as a missional church}

Bosch (1991:372) asserts that a church as a pilgrim is missionary in nature, as found in 1 Peter 2: 9. Here the church is not the sender but the one sent. Her mission (its 'being sent') is not secondary to her being; the church exists in being sent and in building up herself for the sake of mission (Bosch 1991:372). Ecclesiology therefore does not precede missiology because God is a missionary God, and God's people are a missionary people. According to Bosch (1991)

it has become impossible to talk about the church without at the same time talking about mission. Because church and mission belong together from the beginning, a church without a mission or a mission without a church are both contradictions. (p. 372)

Hirsch (2006:284) argues that the term 'missional' is used to describe a certain type or mode of church, leadership, Christianity, etc. For example, a missional church is one whose primary commitment is to the missionary calling of the people of God. Missional leadership is that form of leadership that emphasises the primacy of the missionary calling of God's people, etc. He further defines missional ecclesiology as the area of study that explores the nature of the Christian movements, and therefore the church, as they are shaped by Jesus and his mission. The attention is chiefly on how the church organises and expresses herself when mission is the central focus.

Saayman (Missionalia [April] 2010:5) writes that the term 'missional' as an adjective, especially linked to description 'missional church', has established itself in missiological discourse. In the last decade of the 20th century it was still mainly a term utilised in the developed countries, especially North America and Europe. But towards the end of the first decade in the 21st century, it has established itself also in the developing or non-developed countries, especially in South Africa. He (Saayman 2010:6) also admits that the term mission and missionary as it is generally understood today in theology, namely as spreading of the Christian faith among unbelievers, has a very chequered history.
However, Saayman (2010:8) poses a question: Is the change from missionary to missional indeed nothing more than a case of exchanging a term with a tainted history for an unrelated term with no historical baggage? Have we simply found a good synonym to replace the contested and unacceptable term missionary? Is it not possible that it is not simply a change in terminology, but also an important shift in meaning? Are we talking about the same phenomenon when we talk about the missionary church and the missional church? And do we in fact restore lost credibility by merely exchanging missionary for missional?

The term missional as alternative to the old missionary is actually very new; it started appearing in the mid-1990s in articles and missiological discussions. The first book to introduce this concept to the wider world was only published in 1998 (Billings 2008; Guder 1998). According to Billings (2008:1) the book grew out of the research and discussions conducted by the 'Gospel and our Culture Network'. The main concern of this network is a desire 'to bring the WCC's discussions of missio Dei ('the mission of God') and Leslie Newbigin's missionary insights to bear on North America'.

In the end of his article, Saayman (2010:16) appreciates the fact that the term missional originated from the creative spark of two missionaries and missiologists in the person of David Bosch and Leslie Newbigin from developing countries, and it was imported by North Atlantic countries in their process of contextualisation. Saayman (2010:16) challenges theologians from developing or non-developed countries to decide to utilise the concept, by re-importing a concept which had originated here, and then re-indigenise or re-contextualise the concept to make it really useful.

Therefore, the researcher understands a missional church as a church that defines herself and organises her life around her real purpose as an agent of God's mission to the world. In other words, the church's true and authentic organising principle is mission. When the church is in mission, she is the true church. The church herself not only is a product of that mission, but is also obligated and destined to extend it by whatever means possible. The mission of God flows directly through every believer and every community of faith that adheres to Jesus. To obstruct this is to block God's purposes in and through his people (Hirsch \& Altclass 2009:212).

Meadowlands is one of the more than 30 townships that constitute greater Soweto and where some of the forcefully removed residents of the 'former' western areas of Johannesburg were resettled. It is a township of Soweto adjoining Orlando which is to the east, situated east of Dobsonville and north of Dube. It takes its name from agricultural holdings laid out in 1924. The name is descriptive of the low-lying grassland (Raper 2004). The design and the architectural plan of the houses were inferior and monotonous. There is a striking correlation between the 
demographics of the then western areas and the current Meadowlands. In both situations migrant labourers are tenants and the population is mostly made up of young people; furthermore, the youth constitute a greater number of the unemployed in the area. Meadowlands, similarly to Soweto as a whole, is becoming a class community and poverty is rampant.

The LECSA and PEMS Meadowlands is supposedly a localised expression of the missional character of the church and is situated in Meadowlands Zone One, Soweto, as a parish. The church's physical structure was built in 1972 two years after the researcher was christened at the age of 5 months at the LECSA and PEMS in Jabavu.

As mentioned above, most of the residents of Meadowlands came from WNT, Newclare and Sophiatown as a result of the forced removals of 1955. The role of the LECSA and PEMS during the forced removals is quite opaque, for there is no record of such. One can only deduce from their earlier attitude and stance when the 'winds of change' or decolonisation was blowing through the rest of Africa in the 1950s and 1960s that the church under the leadership of (European) missionaries took an apolitical stance in Lesotho (Mohapeloa 1985:41-42). According to evangelists ('Moleli'), Mr M.P. Matlooane and elder, Mr M.P. Selala, there was a pastoral vacuum during the forced removals and resettlement in Meadowlands for the denomination in South Africa was under the white (European) missionaries who were aloof from the 'people's' struggles.

According to the WCC political changes and challenges in recent years are significantly altering the context in which many churches exist and, therefore, how they seek to understand themselves (WCC 2005:9). Gill et al. (2009:149) record that the heightened political consciousness among the Basotho, including those belonging to the Calvinist Church of Basotho, led to the expulsion, by British colonial authorities, of personalities such as Zephaniah Mothopeng, who was a teacher in Basutoland High School in Maseru, Lesotho, in 1955. Zephaniah Mothopeng later became a political activist in South Africa, was imprisoned on Robben Island and on his release became the President of the Pan Africanist Congress (PAC). No figure could be found at the LECSA and PEMS, be it a minister or lay-person, who was overtly involved in alleviating the plight of the victims of forced removals. This exhibits the church's long-taken position of being quiescent and not fully identifying with the 'suffering'.

\section{Putting the record straight}

The LECSA and PEMS, at the denominational (national) level, does acknowledge and appreciate that she is a product of the missionary enterprise era and thus is forever indebted to her French missionary ancestry (Bianquis 1930:43; Bosch 1991:330; Mohapeloa 1985:38). She (LECSA and PEMS) evinces this through her relationship with the so-called defunct PEMS under the guise of the Evangelical Community for Apostolic Action (ECAA) and DEFAP and by refusing to be totally independent or autonomous from the French mission patronage. The LECSA and PEMS, as a denomination, needs to cut the invisible 'umbilical cord' from the defunct PEMS and assume her position as an authentic African protestant-reformed church in the 21st century and claim her missional space (Casalis 1971:140, 182-183).

The LECSA and PEMS needs to acknowledge, and put it on record, that among other reasons for her 'coming of age' (Thuthuho) in 1964 is the external factors which had to do with the International Missionary Conference (IMC) becoming the WCC, recognising that all work done by the Occident mission organisation over centuries must be handed over to indigenous peoples in those very countries, and the 'winds of change' that captured Africa clamoured for total freedom and independence from the 'West' (Bosch 1991:459; Mohapeloa 1985:46; Saayman 2010:6). External political forces that influenced her missionary independence should be acknowledged in her mission historiography and be transmitted to her ecclesiastical and lay leadership. This should happen so that the denomination may accept that the church operates in the socio-economic-political space, which changes from time to time and should interact missionally with reality (Bosch 1991:2; Saayman 2010:7).

Contrary to Tiyo Soga's observation (Williams 1978:37), not everything that developed in the mission enterprise era can be declared archaic and obsolete, but the maintenance approach of everything that her mission ancestry did smacks of nostalgia and is not sustainable. Since her 'coming of age' (1964-2014) more than 50 years ago, the LECSA and PEMS has done very little in terms of missions, especially in the 21st century. She needs to draw lessons from the mistakes her mission ancestry made when she relied entirely on those in authority, like the royalty, to Christianise the Basotho (Sundkler \& Steed 2000:380). In recent times, the LECSA and PEMS is dependent entirely on formal organisation to do her mission, like her ecumenical connections. Their Baboleli (Evangelists) cannot go beyond the imaginary parochial walls and deputising their ordained parish minister. They should see themselves as the 'cutting edge' of the mission agenda of their parishes and distance themselves from the institutional maintenance approach of doing things.

\section{Lay-ministry}

Moreover, the ordained ministry at the LECSA and PEMS is so institutionalised that lay-ministry is stifled (Hirsch 2006; Mead 1993:22-24). The LECSA and PEMS ministers historically equate the office of the minister in the church with that of a village chief, a model adopted by the early station missionaries (Gill et al. 2009:287, 293; Mohapeloa 1985:40). Was it Jesus Christ of Nazareth, when recruiting disciples, who said: 'Come and follow me for I will make you fishers of men?' That is where lay-ministry comes in. 
They (ministers) must adopt a servant-leadership model (as modelled by Jesus Christ of Nazareth) which resonates with their African adage that 'Morena ke morena ka batho' (A leader or chief is one by the will of the people). Ministers at the LECSA and PEMS must see themselves as the servants of the people, and not the other way around.

The LECSA and PEMS ministers should empower and partner with lay people to do the work of the ministry or mission in their parishes. The mission and ministry of the church currently centre on the clergy and need to be liberated from their clutches. The high institutionalism is not consistent with their Presbyterian type of church government, and thus must be dismantled and replaced with a system that encourages full participation (not just on paper) of the laity in the mission of the church (Hirsch 2006:110; WCC 2005:49). She needs to be authentic to her tradition and belief in the priesthood of all believers (protestant-reformed tradition). The MTS and Bible School should research, conduct refresher courses for their long-serving ministers and expose her students to new and creative ways of becoming a missional church. Lay-ministry training should be taken seriously and not depend on either the time that is available or presbytery conferences. It must be thoroughly researched and informed by the real needs of the church and society. A curriculum of some kind must be developed and delivered by passionate people (both clergy and laity). The best place to conduct this is at the local parish.

\section{Ministerial formation}

The LECSA and PEMS Morija Theological Seminary (MTS) and Bible School, established in 1882 (Casalis 1971:30), are struggling and do not meet the required standard of a credible tertiary institution. The period that the researcher spent, about 3 months, at the MTS was eye-opening. The students' residence was in a dilapidating state, the ablution block was not in usable condition and the kitchen equipment was not up to standard. They have electricity but use a coal stove for cooking, the geyser does not work and students have to use wood to boil water in order to have a warm or hot bath. There are no washing machines and cooking stoves for students, a cafeteria is a luxury and shops are far away should a student be able to afford to buy something. Thus, students spend a lot of their time attending to 'domestic' chores and very little attending to their studies.

With regard to teaching and learning, much is left to be desired. Though the researcher did not attend all lectures, the few he managed to attend were appalling to say the least. Some lecturers would ask students to dictate in English, read aloud, in class and, from time to time, to pause to explain mostly in Sesotho what the passage meant. The researcher's expectation was that students at a tertiary level do most of their reading outside of the lecture room and in the lecture room would raise or engage robustly with what they have read. Those students who attempted to engage with issues in the lecture room were silenced. Most lecturers encountered by the researcher were older and hostile to students and outsiders (for example, the researcher for he is a South African). This is one culture contrary to the spirit of learning and training in the 21st century, especially at an institution of higher learning. Surprisingly, most lecturers are said to hold master's degrees in their field of study.

The library is quite small and the reading material is outdated for students rely on donations from their Occident benefactors. Furthermore, they are lagging behind when it comes to information, communication and technology (ICT). Interviews with some elders at the LECSA and PEMS Meadowlands Parish raised this point as a very serious and pertinent one. Their lecture rooms resemble those in basic education (primary and high school) with chalk boards - they do not appear like lecture rooms. The MTS environment is generally not conducive to higher learning and training. However, it also came to the researcher's attention that a handful of their Lesotho ministers have registered for an Honours Bachelor of Theology with the University of the Free State which is quite an improvement and commendable.

The entire MTS and Bible School need revamping and overhauling and must begin to employ international standards to measure itself against. Qualifications of the lecturers should be scrutinised and potential student's minimum entrance qualifications should be upgraded from Grade 10 (standard 8) to Grade 12 (standard 10), for both ministers and evangelists. Collaboration with other institutions in similar traits and traditions must be pursued -including ecumenical collaboration - and exchange programmes must be encouraged to revitalise and expose both lecturers and students to diverse ways of doing things. As a last resort, the MTS and Bible School may consider merging with other protestant-reformed institutions to train their future ministers and evangelists (Kumalo \& Richardson 2010:265).

\section{Lingua franca}

Frantz Fanon posits that power resembles language, especially in colonial and post-colonial countries. Hence the division between 'inferior' blacks and 'superior' whites reproduces assuming cultures that bear the weight of civilisation. Fanon, therefore, recognises the dual place of language as operating in terms of broader relations of power and as a tool that expresses the world in which people live and their everyday experiences (Fanon 1965:1-3). Consequently, lived experience changes language and so does the way in which people communicate (Alexander et al. 2013:195).

The role of power in language is further examined in the South African context by Neville Alexander (2009) who asserts that the politics of language remain tumultuous, particularly the contestation between English and Afrikaans. However, Charlyn Dyers (2009:266 in Alexander et al. 2013) 
notes that the shifts taking place within South Africa in urban African languages such as tsotsitaal - a mixture of various languages including English, Afrikaans, Sesotho and isiZulu primarily employed by gangsters (Alexander et al. 2013:202) illustrate a 'creative adaptation of new contexts' (Dyers 2009:263 in Alexander et al. 2013:195). In Gauteng townships, particularly, there are multilingual contacts and these townships are considered 'fertile ground for the emergence of lingua francas' (Rudwick in Alexander et al. 2013:195).

The LECSA and PEMS business, or official, language is indeed Sesotho; however, parishes are not restricted. The researcher observed the excitement with which the parishioners at the LECSA and PEMS Meadowlands Parish embraced the Scripture reading from the isiZulu, tshi-Tsonga and English Bible. Moreover, the LECSA and PEMS Maseru Parish is known for holding two Sunday services, one conducted in Sesotho and the other in English. Thus, they are able to attract and reach many people from diverse nationalities because Maseru is the capital city of Lesotho. Therefore, the LECSA and PEMS Meadowlands Parish is permitted to employ any language to carry out her mission in her context. Interestingly, part of the constitution applicable to her Gauteng (South Africa) presbytery is written in English (Molao oa Motheo 2012:88-96). Indeed, language can be a serious barrier to propagating the Gospel or the church in becoming missional; however, for the LECSA and PEMS Meadowlands Parish the challenge is not insurmountable. She must decide for herself what lingua franca would best enable her to reach the target group in her local context. Already the church community at the LECSA and PEMS Meadowlands Parish is multilingual (they or their predecessors originate from the western areas of Johannesburg, like Sophiatown, and they are in the multilingual township of Soweto).

\section{Founding documents: A search for missional mandate}

The LECSA and PEMS Constitution (Molao oa Motheo 2012:4-5,55-59), especially sections 5 and 6 in chapter 1 and chapter 23, has clauses that constitute commissions and committees that must ensure that the denomination engages and responds to missional challenges of her day in different contexts. Therefore, policy should be developed to underpin parish missional engagement and avoid centralising organisational collaboration, especially in the Gauteng (South Africa) presbytery.

The researcher was intrigued by the fact that some elders at the LECSA and PEMS Meadowlands Parish used to complain about certain clauses in the constitution that compel them to always send money to her headquarters in Maseru, Lesotho. But when asked about any constitutional amendments that need to happen to allow the LECSA and PEMS Meadowlands Parish to focus her efforts more locally, they said no constitutional amendments were needed. The impression was that the constitution was standing in
LECSA and PEMS Meadowlands' way of becoming effective missionally in her local context. The LECSA and PEMS Meadowlands Parish is on record pleading and in loggerheads with her headquarters in Maseru to be exempted from paying her dues in order to attend to local building projects.

The missional mandate is explicit from the constitution and almanac (calendar), for it always includes dates that mark environmental issues, HIV, et cetera, of the denomination and the LECSA and PEMS Meadowlands Parish leadership and membership must familiarise themselves with the document. As members of the LECSA and PEMS denomination, they need to embrace the document and cease lamenting that they were not fully consulted when it was amended. If they want to amend the constitution, they would have to workshop the document and speak in unison regarding clauses that need amending and lobby for support. However, the researcher is confident that the LECSA and PEMS constitution has a missional element. Despite this, there is a difference between theory and practice and the LECSA and PEMS Meadowlands Parish should integrate the two and come up with a missional praxis. A missional praxis requires that she constantly reflects on her missional actions as it continues doing acts of missions.

\section{Lack of missional and a prophetic voice}

The LECSA and PEMS Meadowlands should purge herself of the quiescent element of the denomination in favour of a missional church. The quiescent demon that mutes the church when she is supposed to prophetically challenge the status quo must be exorcised. The denomination was quiescent during the forced removals of the western areas of Johannesburg, during the Lesotho political strife and recently when the former Prime Minister Thomas Thabane fleeing to, and seeking refuge in, South Africa and the murder of the head of the Lesotho Defence Force, General Mahau. Ironically, both prime ministers, the former Thomas Thabane and current Phakalitha Mosisili, were at some point in their lives members of the LECSA and PEMS. And yet the church failed to speak prophetically to her communicants. In South Africa, the denomination was silent when miners were massacred at Lonmin Mine in Marikana in the North West, where most of the Basotho men are working as miners. The LECSA and PEMS Meadowlands Parish must continue to clamour and extend herself to the socio-political sphere and agitate for a prophetic voice on the part of her denominational leadership.

The Meadowlands community is predominantly young, while the majority of the LECSA and PEMS Meadowlands Parish communicants are ageing. The missional praxis of the parish would need to take note of this fact and reach out to young people in the area. She needs to find creative ways of tapping into this dormant resource for the 
church. However, it should be noted that it should be 'the whole church taking the whole Gospel to the whole community'. The LECSA and PEMS should further improve on her mission or ministry of providing for orphans, HIV awareness and education, pastoral visits, combating substance and alcohol abuse, ministering through music (choir) and being in solidarity (Alexander et al. 2013:115) with workless households during these tough economic times.

\section{A proposed intervention plan for the Lesotho Evangelical Church in Southern Africa and Paris Evangelical Missionary Society Meadowlands Parish}

The researcher proposes an intervention plan that will, in a small way, assist in sensitising and galvanising the LECSA and PEMS Meadowlands membership to continue struggling to become a missional church (see Box 1).

\section{Conclusion}

The article reflected on the struggle of the LECSA and PEMS Meadowlands Parish in becoming a missional church employing Positive Deconstruction as a methodology, highlighting what is working and effective and what is not. The LECSA and PEMS Meadowlands Parish is a survivor and her challenges today - language policy, finances, ministerial formation, unity issues, membership exodus, layministry development, institutionalisation of ministry, ecumenical participation, mission and evangelism - are not insurmountable.

The researcher sees that the LECSA and PEMS Meadowlands Parish appreciate her missional heritage dating from the times of missionary enterprise of the 19th century, her survival of the forced removals of the western areas of Johannesburg and resettling in the South Western Township (Soweto) which later became the stronghold of black resistance against apartheid. The future of the LECSA and PEMS Meadowlands Parish is that which capitalises on missional opportunities at her disposal like, inter alia, providing for orphans, HIV awareness and education, pastoral visits, combating substance and alcohol abuse, ministering through music (choir) and solidarity with workless households.

The LECSA and PEMS Meadowlands Parish needs to take advantage of the demographic fact that the youth happen to be in the majority in the township and thus presenting an opportunity for outreach programmes for the youth and continuity.

Their resistance spirit of the western areas of Johannesburg and Soweto's propensity to struggle and protest must live on. They must continue clamouring and agitating for missio Dei in their space and for the benefit of the younger generation. They must continue struggling to become a missional church.

\section{Acknowledgements}

\section{Competing interests}

The authors declare that he has no financial or personal relationships which may have inappropriately influenced them in writing this article.

\section{Author contributions}

This article is based on the MA-thesis of L.T.K. and as such he is the main author. T.S.K. was the supervisor of the thesis and is the contributing author.

BOX 1: The proposed plan for LECSA and PEMS Meadowlands Parish.

\begin{tabular}{|c|c|}
\hline The problem statement & The struggle of the LECSA and PEMS in Meadowlands, Soweto, in becoming a missional church \\
\hline The nature of the planned intervention or project & $\begin{array}{l}\text { 1. Conduct a workshop for the leadership to familiarise themselves with the LECSA and PEMS constitution and } \\
\text { decide on her lingua francas. } \\
\text { 2. Conduct lay-minister training on missional church and adopt a missional praxis. } \\
\text { 3. Organise a celebration or commemoration on the struggle and resistance in the western areas of Johannesburg. } \\
\text { 4. Conduct a seminar on prophetic ministry or mission. } \\
\text { 5. Hold a session on dealing with and healing the past (address the forced removals). } \\
\text { 6. Develop a robust youth ministry programme. }\end{array}$ \\
\hline $\begin{array}{l}\text { The aims and objectives (intended outcomes) of the } \\
\text { intervention }\end{array}$ & $\begin{array}{l}\text { 1. To share the findings of this article } \\
\text { 2. To have a clear understanding of the LECSA and PEMS constitution } \\
\text { 3. To adopt a missional praxis and programme for the LECSA and PEMS Meadowlands Parish } \\
\text { 4. To share experience with the LECSA and PEMS Gauteng (South Africa) Presbytery Committee's Commission on } \\
\text { Evangelism or Mission (Komisi ea Lentsoe) } \\
\text { 5. To duplicate the plan to all the parishes within the Gauteng (South Africa) Presbytery }\end{array}$ \\
\hline The members of the support group/task team & $\begin{array}{l}\text { Their role as leaders in LECSA and PEMS Meadowlands Parish: } \\
\text { 1. Mr Michael P. Matlooane: a long-serving, senior citizen and passionate 'Moleli' (evangelist) who grew up in the } \\
\text { western areas of Johannesburg } \\
\text { 2. Mr Marapo Mapeshoane: The minster-in-charge } \\
\text { 3. Ms Lisebo Sephaka: a long-serving, senior citizen in the Women Guild (Bo'Mabana) and elder who grew up in the } \\
\text { western areas of Johannesburg } \\
\text { 4. Mr Joe Ramadibane: a long-serving youth leader } \\
\text { 5. Ms Kekeletso Moeno: a long-serving, middle-aged woman, choir leader, youth leader and an elder } \\
\text { 6. Ms Mpolai Nkhetsi: another long-serving, middle-aged woman and an elder } \\
\text { 7. Rev. Teboho Morapeli: an ordained minister of the LECSA and PEMS and moderator of the Gauteng (South Africa) } \\
\text { Presbytery } \\
\text { 8. Tsidiso Kganyapa: the researcher of this article }\end{array}$ \\
\hline $\begin{array}{l}\text { The timeframe for the project (when does it begin } \\
\text { and end?) }\end{array}$ & To be decided \\
\hline
\end{tabular}

Source: Author's own work 


\section{References}

Alexander, N., 2009, Mother Tongue Based Bilingual Education in Africa: A Cultura and Intellectual Imperative, Springer Verlag, Berlin.

Alexander, P., Ceruti, C., Motseke, K., Phadi, M. \& Wale, K., 2013, Class in Soweto, UKZN Press, Pietermaritzburg.

Ashley, A., 1980, Peace-making in South Africa: The life and work of Dorothy Maud, New Horizon, Bognor Regis.

Beall, J., Crankshaw, O. \& Parnell, S., 2003, 'Social differentiation and Urban Governance in Greater Soweto', in R. Timlinson et al. (eds.), Emerging Johannesburg: Perspectives on the post-apartheid city, pp. 97-110, Routledge, New York.

Beavon, K., 2004, Johannesburg: The making and shaping of the city, UNISA Press, Pretoria.

Bianquis, J., 1930, Les Origines de la Société des Missions, 1822-1829, Société des missions évangéliques, Paris.

Billings, J.T., 2008, 'What makes a church missional?', Christianity Today 3(5), 2 p viewed 1 July, from http://www.christianitytoday.com/ct/2008/march/16.56.htm/

Bonner, P., 1990, 'Desirable or undesirable Sotho women? Liquor, prostitution and the Migrand of Sotho women to the rand', in C. Walker (ed.), Women and gender in Southern Africa to 1945: An overview, pp. 30-40, New Africa Books, London.

Bosch, D.J., 1991, Transforming mission: Paradigm shifts in theology of mission, Orbis, Maryknoll, NY.

Brown, R., 2013, A native of nowhere: The life of Nat Nakasa, Jacana, Johannesburg. Casalis, E., 1971, My life in Basutoland, Struik Publishers, Capet Town.

Couzens, T., 2003, Murder at Morija, Random House Publishers, Johannesburg.

De Clark, S.G., 2002, The Evangelical Missionaries and the Basotho, 1833-1933, UNISA Press, Pretoria.

Du Plessis, J., 1965, Christian Missions in South Africa, Struik Publishers, Cape Town.

Fanon, F., 1965, Black skins, white masks, Pluto Press, London.

Gill, S.J., Malahleha, G.G.M., Mashologu, M.T., Pule, S.M. \& Sibolla, M.E., 2009 Mekolokotoane Kerekeng ea Evangeli Lesotho, Jubilee Highlights 1833-2008, Morija Museum and Archives, Morija.

Goodhew, D., 2004, Respectability and resistance: A history of Sophiatown, Praeger, London.

Guder, D.L., 1998, Missional Church: A vision for the sending of the church in North America, Eerdmans Publishing Company, Grand Rapids, MI.

Hirsch, A., 2006, The forgotten ways: Reactivating the missional Church, Brazos, Grand Rapids, MI.

Hirsch, A. \& Altclass, D., 2009, The forgotten ways, Brazos Press, Grand Rapids, MI.
Kagan, N., 1978, 'African settlements in the Johannesburg Area, 1903-23', Masters' thesis, University of the Witwatersrand.

Kane-Berman, J., 1978, Soweto: Black Revolt, white reaction, Raven, Johannesburg.

Kumalo, S. \& Richardson, N., 2010, 'Seth Mokitimi and education for ministry: What's in a name?', Missionalia 38(2), 259-274.

Mason, J., 2002, Qualitative research, 2nd edn., Sage, London.

Mead, B.L., 1993, Transforming congregations for the future: The once and future Church: Reinventing the congregation for a new mission frontier, The Alban Institute, New York.

Modisane, W.B., 1990, Blame me on history, Penguin, Harmondsworth.

Mohapeloa, J.M., 1985, From mission to Church: Fifty years of the work of the Paris Evangelical missionary society and the Lesotho Evangelical Church 1933-1983, Morija Sesuto Book Depot, Morija.

Ngwane, T., 2003, 'A movement of movements? Sparks in the township', New Left Review 22, 37-56.

Pollard, N., 1997, Evangelism made slightly less difficult, InterVarsity Press, Downers Grove, IL.

Purkey, M. \& Stein, P. (eds.), 1993, Sophiatown: A play by junction avenue theatre company, Wits University Press, Johannesburg.

Raper, E.P., 2004, New dictionary of South African place names, Jonathan Ball, Johannesburg.

Saayman, W., 2010, 'Missionary or missional? A study in terminology', Missionalia 38(1), 5-16.

Saha, T.K. et al., 2012, Kereke ea Evangeli Lesotho e Boroa ho Afrika.: Molao oa Motheo, Morija Printing Works, Morija.

Seekings, J., 2011, 'Race, class and inequality in the South African city', in G. Bridge \& S. Watson (eds.), The new Blackwell companion to the city, pp. 175-189, Blackwell Publishing, Chichester.

Sundkler, B. \& Steed, C., 2000, A history of the Church in Africa, Cambridge University Press, Cambridge.

Swinton, J. \& Mowat, H., 2006, Practical theology and qualitative research, SCM Press, London.

Thema, D., 1999, Kortboy: A Sophiatown legend, Kwela Books, Cape Town.

Van Holdt, K. \& Webster, E., 2005, Work restructuring and the crisis of social reproduction, University of Kwa-Zulu Natal Press, Pietermaritzburg.

Williams, D., 1978, Umfundisi: A biography of Tiyo Soga 1829-1871, Lovedale Press, Lovedale.

World Council of Churches (WCC), 2005, The nature and mission of the Church: A stage on the way to a common statement, Faith and Order Paper 198, World Council of Churches, Geneva. 